\title{
DELAYED IMPLANTATION IN INTACT RATS TREATED WITH MEDROXYPROGESTERONE ACETATE
}

\author{
LESTER E. BARNES* AND ROLAND K. MEYER \\ Department of Zoology, University of Wisconsin, \\ Madison 6, Wisconsin, U.S.A. \\ (Received 24th Fuly 1963)
}

\begin{abstract}
Summary. Intact, female Holtzman rats were treated daily with medroxyprogesterone acetate (MAP; Provera) in corn oil, beginning on the day of insemination. This caused delay of implantation in $14 \%$ $(0.5 \mathrm{mg} /$ day $)$ to $100 \%(2.4 \mathrm{mg} /$ day $)$ of the animals tested. It is possible that MAP suppresses the synthesis or the release of luteinizing hormone $(\mathrm{LH})$ from the pituitary gland and thus prevents the production of sufficient endogenous oestrogen to cause implantation.

Implantation was achieved in 'delayed' rats by simultaneous administration of $1 \mathrm{\mu g}$ of oestrone with the dose of MAP they had been receiving. The viability of foetuses in such animals varied inversely with the dose of MAP the mothers had received.
\end{abstract}

\section{INTRODUCTION}

Delay of nidation of blastocysts is a phenomenon which occurs naturally and regularly in some wild species of mammals (Eckstein, Shelesnyak \& Amoroso, 1959). It also occurs in pregnant, lactating laboratory rats and mice (Enzmann, Saphir \& Pincus, 1932; Mayer, 1959). The condition can be induced experimentally in rats by ovariectomy and treatment with progesterone after fertilization but before implantation has occurred. Animals treated in this way will retain blastocysts free in the uterus in a viable condition for long periods of time or until they are induced to implant by oestrogen administration. This procedure has been described by Cochrane \& Meyer (1957) from this laboratory as well as by other investigators.

Delayed nidation can be induced experimentally in rats by auto-grafting the anterior pituitary gland to the kidney capsule on the 2nd day of pregnancy (Cochrane, Prasad \& Meyer, 1962). In these animals also, nidation is delayed until the blastocysts are induced to implant by treatment with oestrogen.

There are no reports in the literature of implantation being delayed in intact rats by the administration of progesterone alone. Progesterone at a single daily dose of $16 \mathrm{mg}$ (Cochrane \& Meyer, 1957) or even as high as $40 \mathrm{mg} / \mathrm{day}$ in divided doses (J. S. Schlough, personal communication) did not cause delayed implantation in intact rats. MAP, a powerful progestin with pituitary-inhibiting

* Public Health Service Pre-doctoral Fellow. Present address: The Endocrine Laboratories, Madison, Wisconsin, U.S.A. 
activity, has already been shown to be capable of delaying nidation in intact rats (Barnes \& Meyer, 1960); this paper reports further studies on this property of MAP.

\section{MATERIALS AND METHODS}

Female rats, 80 to 120 days of age, obtained from the Holtzman Company, were mated with fertile males. Beginning on the day of insemination (Day 1 of pregnancy) animals were injected daily with MAP* subcutaneously in $0.25 \mathrm{cc}$ of corn oil through Day 13. Laparotomies were performed on Days 8 and 13 to determine whether implantation had occurred. Animals that showed no implantation sites by Day 13 were given a subcutaneous injection on Day 14 of $0.25 \mathrm{cc}$ of corn oil containing both $1 \mu \mathrm{g}$ of oestrone and the dose of MAP which they had been receiving. This combined treatment was continued through Day 18 at which time a third laparotomy was performed to determine if implantation sites were present. If sites were present on Day 18, the oestrone-MAP treatment was continued to Day 29 at which time all animals were autopsied and the condition, location and numbers of foetuses found in the uterus were noted and compared with the implantation sites observed at laparotomy on Day 18. Day 29 was chosen for the day of autopsy on the basis that blastocysts which had been induced to implant by initiating oestrone treatment on Day 14 would be developed to a degree comparable with 19-day foetuses from normal pregnancies.

Some animals were found to have implanted by Days 8 or 13; these were either continued on treatment with MAP alone, or, in some cases, treated with oestrone to see whether additional implantations would occur. Additional implantations were not observed in any of these animals. Some of the animals which had implanted spontaneously (prior to oestrone treatment) were continued on MAP treatment and allowed to proceed to term in order to observe whether normal parturition was possible. In no case did these animals deliver their young; the pregnancies were simply extended several days beyond the normal length, after which the foetuses died. The mothers eventually also succumbed, probably because of the accumulation of toxic materials from their dead foetuses.

A few animals were treated with higher doses of oestrogen on the day calculated to be the normal time for parturition (15th day after implantation). The rationale for this was as follows: it is known that progesterone has a quieting effect upon uterine musculature and prevents strong contractions until the excitatory action of oestrogen can prevail. In this experiment, therefore, we administered additional oestrogen in an attempt to override the effect of the progestin but parturition did not occur.

\section{RESULTS}

The results of the experiments on a series of animals are shown in Table 1. It is seen that a daily dose of $2.4 \mathrm{mg}$ of MAP caused delay of nidation in all the animals tested. This was accompanied, however, by extremely low viability of

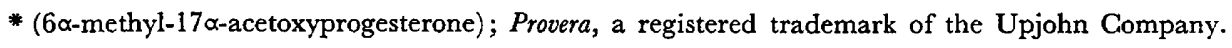


the foetuses which developed following oestrogen-induced implantation. As the dose of MAP was reduced, there was an increase in the percentage of spontaneous implantation, but also an increase in the number of living foetuses that were recovered at the time of autopsy. At the doses tested, $0.5 \mathrm{mg}$ was the lowest dose which was effective in causing delayed implantation; at this dose level only one of seven animals showed delay of implantation. However, all except one of the sites which had been observed in this animal at laparotomy on Day 18 survived to the day of autopsy.

TABLE 1

TREATMENT OF FEMALE RATS WITH MAP DURING DAYS 1 TO 29 OF PREGNANGY

\begin{tabular}{|c|c|c|c|c|c|c|c|c|}
\hline \multirow{2}{*}{$\begin{array}{l}\text { Daily dose } \\
\text { MAP }(m g)\end{array}$} & \multirow{2}{*}{$\begin{array}{l}\text { No. } \\
\text { rats }\end{array}$} & \multicolumn{3}{|c|}{$\begin{array}{l}\text { No. animals having } \\
\text { implantation sites } \\
\text { first observed on: }\end{array}$} & \multirow{2}{*}{$\begin{array}{l}\text { Animals with } \\
\text { delayed implantation } \\
(\%)\end{array}$} & \multicolumn{3}{|c|}{$\begin{array}{l}\text { Condition of foetuses } \\
\text { at autopsy }(\text { Day 29)* }\end{array}$} \\
\hline & & $\begin{array}{c}\text { Day } \\
8\end{array}$ & $\begin{array}{c}\text { Day } \\
13\end{array}$ & $\begin{array}{c}\text { Day } \\
18\end{array}$ & & $\begin{array}{l}\text { Average } \\
\text { alive }\end{array}$ & $\begin{array}{l}\text { Average } \text { No. }^{\text {dead }} \\
\text { deat }\end{array}$ & Viable $(\%)$ \\
\hline $\begin{array}{l}2.4 \\
1.5 \\
1.0 \\
0.5 \\
0.1\end{array}$ & $\begin{array}{r}9 \\
14 \\
10 \\
7 \\
5\end{array}$ & $\begin{array}{l}0 \\
0 \\
1 \\
6 \\
5\end{array}$ & $\begin{array}{l}0 \\
4 \\
1 \\
0 \\
-\end{array}$ & $\begin{array}{r}9 \\
10 \\
8 \\
1 \\
-\end{array}$ & $\begin{array}{r}100 \cdot 0 \\
71 \cdot 5 \\
80.0 \\
14.3 \\
0.0\end{array}$ & $\begin{array}{l}0 \cdot 33 \\
4 \cdot 2 \\
4 \cdot 0 \\
6 \cdot 0 \\
-\end{array}$ & $\begin{array}{c}9 \cdot 7 \\
6 \cdot 0 \\
7 \cdot 1 \\
1 \cdot 0 \\
-\end{array}$ & $\begin{array}{r}3 \cdot 3 \\
41 \cdot 2 \\
36 \cdot 0 \\
85 \cdot 0 \\
-\end{array}$ \\
\hline Controls† & 7 & 7 & - & - & 0.0 & $9 \cdot 7$ & 0.8 & 91.5 \\
\hline
\end{tabular}

Oestrone treatment ( $1 \mu \mathrm{g} /$ day) from Days 14 to 29.

* Except for untreated control animals, data shown are from only those animals which had not implanted before oestrone administration was begun. Percentages are based on number of sites counted at laparotomy on Day 18, after oestrone administration.

t Control animals were normal, pregnant animals which were laparotomized on Days 8 and 13. Autopsy was performed on Day 19 of pregnancy.

We have found that blastocysts are maintained in the delayed condition for extended periods. We have flushed the uteri of MAP-treated animals and recovered blastocysts 45 days after insemination. A low-power microscopic examination of such blastocysts shows them to be similar to late, pre-implantation blastocysts from untreated, pregnant rats.

We have initiated nidation after a long period of delay by the administration of oestrone 32 days after insemination, but no foetuses survived to the day of autopsy. However, when the delay period is shorter, i.e. when oestrone is begun either 20 or 15 days after insemination, approximately $20 \%$ of the foetuses survived.

\section{DISCUSSION}

The mechanism by which MAP causes delay of implantation in intact rats is being studied. The substance is known to be a powerful progestational agent as determined by proliferation of rabbit uterine endometrium, and it has also been shown to inhibit ovulation in the rabbit when administered orally or parenterally at doses much lower than progesterone itself (Barnes, Schmidt \& Dulin, 1959). This latter action is believed to be due to MAP preventing the release of 
LH which is necessary for pre-ovulatory follicular swelling and ovulation. MAP also has the ability to prevent the so-called 'castration hypersecretion' of gonadotrophins from the pituitary of the castrate partner of rats in parabiosis (Shipley, 1962; E. G. Shipley, R. K. Meyer \& L. E. Barnes, unpublished data).

We suggest that the mechanism responsible for the action of MAP in delaying nidation in intact rats is the suppression of gonadotrophic hormone production or release so that the ovaries fail to secrete oestrogen in quantities sufficient to induce nidation.

Microscopic examination of ovaries from MAP-treated, pregnant rats reveals that the corpora lutea in such ovaries are extremely small and atrophic as compared to those from untreated, pregnant animals; also the interstitial tissue as well as the corpora contain many 'deficiency cells', believed to be indicative of a lack of LH (Evans, Simpson \& Pencharz, 1937). The directly progestational effects of MAP, however, maintain the blastocysts in a viable condition and they implant when exogenous oestrogen is given; the continued oestrogen-progestin treatment allows them to develop normally.

The relatively high mortality of foetuses in animals treated with high doses of MAP may be explained as being due to either a direct injurious effect of this synthetic progestin on the foetus or to an oestrogen-progestin ratio unfavourable to continued development. Lower doses are less deleterious; the work of Stucki (1958) has shown that doses of MAP up to $20 \mathrm{mg}$ /day beginning on Day 8 of pregnancy, had no apparent deleterious effect on the survival of young in ovariectomized pregnant rats. This would indicate that the low rates of survival of foetuses from rats receiving high doses of MAP in this present experiment were due to some factor other than a direct toxicity of the compound or that the effect was greater prior to Day 8. Unlike Stucki's work, in which MAP was administered only after implantation had been accomplished, in our work all events of pregnancy took place in an environment influenced by this compound, so that there was opportunity for it to exert more striking effects upon the pregnancies.

The survival of blastocysts in MAP delay provides a means for study, in the intact rat, of blastocyst-uterine relationships in implantation. Use of the MAPdelayed implantation in the rat has been described recently by Duncan \& Lyster (1963) for their studies of an anti-oestrogenic compound and its effects on blastocyst survival.

\section{ACKNOWLEDGMENTS}

These studies were supported in part by Grant A-804(C-13), National Institute of Arthritis and Metabolic Diseases, U.S.P.H.S. and by Public Health Service Fellowship GPM-15,066.

\section{REFERENCES}

Barnes, L. E. \& MEYer, R. K. (1960) Induction of delayed implantation in intact rats by Provera

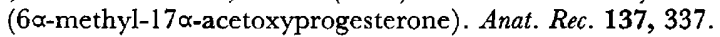

Barnes, L. E., Schmidt, F. L. \& Dulin, W. E. (1959) Progestational activity of $6 \alpha$-methyl-17 $\alpha$-acetoxyprogesterone. Proc. Soc. exp. Biol., N.Y. 100, 820.

Cochrane, R. L. \& Meyer, R. K. (1957) Delayed nidation in the rat induced by progesterone. Proc. Soc. exp. Biol., N.Y. 96, 155. 
Cochrane, R. L., Prasad, M. R. N. \& Meyer, R. K. (1962) Delayed nidation in the rat induced by autografts of the hypophysis with a case report of "Asynchronous Implantation". Endocrinology, 70, 228.

Duncan, G. W. \& Lyster, S. C. (1963) Effect of a diphenylindene derivative (U-1 I555A) on blastocyst survival in utero. Fertil. Steril. 14, 565.

Eckstein, P., Shelesnyak, M. C. \& Amoroso, E. G. (1959) A survey of the physiology of ovum implantation in mammals. Mem. Soc. Endocrin. 6, 3.

Enzmann, E. V., Saphir, N. R. \& Pincus, G. (1932) Delayed pregnancy in mice. Anat. Rec. 54, 325.

Evans, H. M., Simpson, M. E. \& Pencharz, R. I. (1937) An anterior pituitary gonadotropic fraction (ICSH) specifically stimulating the interstitial tissue of testis and ovary. Cold Spr. Harb. Symp. quant. Biol. 5, 229.

MAYER, G. (1959) Recent studies on hormonal control of delayed implantation and superimplantation in the rat. Mem. Soc. Endocrin. 6, 76.

ShIPLEY, E. G. (1962) Anti-gonadotrophic steroids, inhibition of ovulation and mating. Methods in Hormone Research, vol. II, p. 179. Ed. Ralph I. Dorfman. Academic Press, New York.

STUсKI, J. C. (1958) Maintenance of pregnancy in ovariectomized rats with some newer progestins. Proc. Soc. exp. Biol., N.Y. 99, 500. 